\title{
Regulatory Techniques and Liability Regimes for Asset Managers
}

By

\author{
Deborah A. DeMott ${ }^{*}$
}

\section{INTRODUCTION}

Asset management, a distinctive component of segment for financial services and products, has not attracted scholarly interest to the extent warranted by its significance and the complexity of the issues it raises. In general, in an asset-management relationship an investor has delegated discretion to a manager — the investor's agent — to make decisions respecting securities on the investor's behalf, subject to limitations and objectives established in an investment management agreement. Measuring the size of the industry requires many judgment calls, but a reputable source reckons that, world-wide, asset managers had $\$ 121.8$ trillion dollars under management in 2011. ${ }^{1}$ As Liability of Asset Managers documents extensively, across a range of jurisdictions, important issues raised by asset management are resolved differently, sometimes strikingly so. This is so within the EU under the MiFID regime, and well as within major nonEU jurisdictions: Switzerland, Canada, and the United States.

It is also evident that regulation specific to asset management has not displaced general law; general law — the law of agency (or representation), contract, and tort — shapes the content of regulation and influences how questions are resolved, in particular when client's portfolio

*David F. Cavers Professor of Law, Duke University School of Law. This paper originated with a talk at the symposium to launch D. Busch \& D.A. DeMott (eds.), Liability of Asset Managers (OUP, 2012), sponsored by the Institute for Financial Law, Radboud University Nijmegen, Amsterdam, April 20, 2012.

${ }^{1}$ Boston Consulting Group, Global Wealth 2011: Shaping a New Tomorrow (2011). 
suffers losses or the asset manager's loyalty to the client is at issue. Additionally, the jurisdictions covered by Liability of Asset Managers answer differently a series of questions about relationships between regulation and managers' civil liability (whether grounded in a breach of duties imposed by regulation or by the general law), suggesting different answers to the broader question whether regulation and civil liability should be understood as substitutes for each other or as complements. The relationships between regulation and civil liability are complex and are not resolved uniformly across jurisdictions, even EU jurisdictions subject to MiFID. $^{2}$

Even from my vantage point in the United States, the liability of asset managers cannot be assessed without considering backdrop bodies of law. ${ }^{3}$ The relevant federal statute, the Investment Advisers Act of 1940, plus an extensive body of administrative rules issued by the SEC under the Act, do not entirely occupy the field despite their long history and technical complexity. To be sure, the precise definition of the actors covered by the Advisers Act is not identical to MiFID's definition of those engaged in 'portfolio management' of 'financial instruments' because the Act encompasses investment advice given generally without mentioning a particular security as well as advice about the selection of another adviser. ${ }^{4}$ On the

${ }^{2}$ See D. Busch \& D.A. DeMott, 'Comparative Analysis of the Jurisdictions-The Impact of Regulatory Frameworks on an Asset Manager's Private Law Duties and Liability, in D. Busch \& D.A. DeMott, Liability of Asset Managers (OUP 2012)(hereinafter Liability of Asset Managers).

${ }^{3}$ See D.A. DeMott \& A.B. Laby, 'United States of America,' in Liability of Asset Managers ch. 13.

${ }^{4}$ Compare Advisers Act, s 202(a)(11), 15 USC s 80b-(a)(11) with Markets in Financial Instruments Directive 2004/39/EC of 21 April 2004, Title I, Art 4(1)(9)(hereinafter 'MiFID'). 
other hand, not all who manage investments in securities for others fall within the scope of the Advisers Act; for one thing, the Act is limited to advice about 'securities,' which does not include swaps, futures, and other instruments covered by MiFID's definition of 'financial instrument'. ${ }^{5}$ Nonetheless, sufficient overlap suggests the relevance of experience in the United States, in particular its combination of a long-enduring regulatory structure with elements that evolve gradually. These include ongoing regulatory determinations, plus judicial decisions applying the Advisers Act and the general law.

General law (and civil liability) aside for the moment, another striking feature of the regulation of asset managers across jurisdictions is the lengthy menu of regulatory techniques in use, albeit unevenly and with different emphases and styles. The remainder of this brief Comment sketches some of these techniques and issues they raise, prefaced by a brief discussion of goals and objectives in the regulation of asset managers.

\section{REGULATORY OBJECTIVES AND TECHNIQUES}

\section{A. Regulatory objectives}

In general, and across jurisdictions, the reduction of agency costs is a central objective of regulating asset managers. Such costs stem from divergent interests as between manager and client. ${ }^{6}$ The fact of regulation acknowledges that asset management contracts may be inadequate vehicles through which to reduce agency costs, that an asset manager's interest in developing

\footnotetext{
${ }^{5}$ Compare Advisers Act s 202(a)(11) with MiFID Art 4(1)(17).

${ }^{6}$ See generally E. Wymeersch, 'Conflicts of Interest, Especially in Asset Management,' in Conflicts of Interest (L. Thévenoz \& R. Bahar eds)(Kluwer 2007).
} 
and preserving a good reputation may not resolve the consequences of divergent interests between manager and client, and that the interests of asset managers as members of an industry may fall short of aligning managers' and clients' interests. Separately, asset managers intermediate information about the value of underlying investment assets as between managers' clients and the issuers of investment securities. Asset managers filter information that issuers generate and are a component force in securities pricing through decisions to buy and sell securities. ${ }^{7}$ To the extent managers' investment decisions are biased by conflicts of interest, systemic concerns about the integrity of market pricing come into play beyond a manager's relationship with a particular client.

The regulation of asset managers may reflect additional commitments and objectives. Regulation within the EU has been shaped by overarching commitments to stronger integration of securities markets in Europe ${ }^{8}$ and a corollary commitment to achieving a level playing field across EU jurisdictions for providers of financial services. This does not appear to be a dominant regulatory objective in the United States and Canada. Additionally, although furthering legal certainty is an underlying aspiration of contemporary regulation, in the United States and Canada this objective co-exists with the consequences of federalism and the bottom-up development and application of general legal principles, in Canada encompassing a civil-code jurisdiction (Quebec) as well as provinces within the common-law tradition. ${ }^{9}$

${ }^{7}$ See J.D. Cox et al, Securities Regulation 1003-4 (Aspen $5^{\text {th }}$ ed 2009).

${ }^{8}$ See C.M. Grundmann-van de Krol, 'The Markets in Financial Instruments Directive and Asset Management,' para. 2.05, in Liability of Asset Managers.

${ }^{9}$ See P. Hughes \& C. Jordan, 'Canada,' para 14.209, in Liability of Asset Managers. 
Distinct from the substance of regulatory commitments and techniques, how best to assure compliance with regulation is an overarching question. Most likely complex regulatory systems, to the extent they succeed, do so not on the ex ante basis of architectural design, but because the targets of regulation participate in achieving the regulatory mission. ${ }^{10}$ Whether it occurs through command-and-control regulation or through principles-based regulation that relies on individual firms and industry-based groups, compliance is an inescapable (and large) question about the effectiveness of regulation. ${ }^{11}$

\section{B. Regulatory techniques}

Although asset managers are subject to similar types of regulation in many jurisdiction, the fact of diversity in regulatory technique is striking, as is the complementarity among regulatory techniques. For example, in Switzerland, unquestionably a significant jurisdiction, asset management as such is not a regulated financial service. ${ }^{12}$ However, industry-based selfregulation is important, ${ }^{13}$ in particular because clients with discretionarily-managed assets do not have access to investment in hedge funds and the like unless their manager has the status of a bank or securities dealer or is a member of a self-regulatory organization with a code of conduct that binds its members and complies with requirements imposed by the Swiss Financial Market

\footnotetext{
${ }^{10}$ See A. Riles, Collateral Knowledge 277 (CUP 2011).

${ }^{11}$ See J. Black, 'The Forms and Paradoxes of Principles-Based Regulation,” 3(3) Capital Markets Law Journal 425, 444-45 (2008). 10.

${ }^{12}$ L. Thévenoz \& C. Bretton-Chevalier, 'Switzerland,' in Liability of Asset Managers ch

${ }^{13}$ Id. paras. 10.11-10.19.
} 
Supervisory Authority (FINMA). ${ }^{14}$

Regulation specific to asset managers tends to use some or all among a set of techniques, which are: (1) mandated disclosure of information, in particular concerning the manager and the terms under which a portfolio will be managed; (2) registration, licensing, and other requirements that determine eligibility to provide management services; (3) self-regulation by industry-based organizations; and (4) rules that structure the manager's conduct of business, including custody of client assets. Jurisdictions also differ in what may be termed the "style" of regulation, in particular the character of enforcement by the regulator itself, but this brief Comment does not explore this dimension of difference.

\section{Mandated disclosure of information}

Given its central role in contemporary securities regulation, it is unsurprising that regulation specific to asset managers requires disclosure by the manager of specified information to clients and prospective clients. MiFID, for example, requires that clients and potential clients be provided with information in a standardized format appropriate to understanding the nature and risks associated with investment services, ${ }^{15}$ with differences depending on whether a client or potential client is a retail investor or a professional. ${ }^{16}$ For retail clients, this includes information about the method and frequency with which portfolio holdings will be valued, details of any delegation of discretionary management authority, any benchmark for portfolio

\footnotetext{
${ }^{14} \mathrm{Id}$.

${ }^{15} \mathrm{MiFID}$ art 19(3).

${ }^{16}$ See Grundman-van de Krol, supra, para. 2.80-2.82.
} 
performance, and the types of financial instruments to be included in the portfolio. ${ }^{17}$ In the United States, disclosure of information is the primary duty imposed on investment advisers by the Advisers Act. ${ }^{18}$ Advisers are subject to specific disclosure requirements and, more generally, to a general duty of disclosure that encompasses conflicts of interest as between the adviser and its client, even when the adviser believes the conflict does not affect its recommendations or decisions. ${ }^{19}$

How extensively or heavily a regulatory system should rely on required disclosure is a noticeable difference among jurisdictions, creating a spectrum on which the United States has long emphasized disclosure as a preferred technique of regulation. Indeed, in the evolution of MiFID II, the European Commission proposed a prohibition on the payment of commissions to an investment adviser when the adviser is designated as an independent adviser ${ }^{20}$ Whether or not (and in what form) the prohibition may survive into the final version of MiFID II, ${ }^{21}$ the choices of regulatory technique lie among required disclosure of commissions, versus their prohibition, versus their treatment in the present MiFID regime, in which commissions may be accepted if they are 'value-adding,' enhancing service to the client. ${ }^{22}$

\footnotetext{
${ }^{17}$ Id. para. 2.82 .
}

${ }^{18}$ DeMott \& Laby, supra, para 13.49.

${ }^{19}$ Id.

${ }^{20}$ See Proposal for MiFID II of 20 October 2011, COM (2011) 656 final, Art 25 (5)-(6).

${ }^{21}$ On the flux surrounding this question, see N. Reeve, 'Mifid II: Where now for a Europe-wide commission ban?' FT Adviser July 3, 2012.

${ }^{22}$ Grundmann-van de Krol, supra para 2.74. 
The universality of disclosure requirements may tend to slight questions about the efficacy of disclosure in enabling clients to make informed choices. Academic researchers using the methodology of experimental economics find that disclosure of conflicts of interest by financial advisers has paradoxical results. ${ }^{23}$ On the one hand, if an adviser discloses a conflictin the study a payoff based on the amount a client invests - clients fail to discount enough for the adviser's bias. This may be because disclosure induces greater confidence in the adviser, especially when the disclosure appears to be made voluntarily, or because clients find it hard to know how much to discount a recommendation and find it hard to unlearn what they previously believed. On the other hand, advisers required to disclose conflicts seemed to give advice that was more biased or exaggerated, perhaps because the disclosure requirement conferred a 'moral license $^{, 24}$ to bias advice and to disclose conflicts in a perfunctory manner. To be sure, such studies are necessarily limited by the methodologies used but the results may warrant caution about the consequences of mandated disclosure.

\section{Licensing, registration, and other eligibility requirements}

With the exception of Switzerland as noted above, asset managers generally must comply with a licensing or registration requirement administered by a public regulatory authority, unless the manager is exempt from the requirement. The content of these requirements differs. MiFID requires prior authorization to perform investment management services, membership in a client compensation scheme, and compliance with stated minimum capital requirements. For example,

\footnotetext{
${ }^{23}$ D.M. Cain et al, 'The Dirt on Coming Clean: Perverse Effects of Disclosing Conflicts of Interest,' 34 Journal of Legal Studies 1 (2005).

${ }^{24}$ Id. at 7.
} 
in England, Wales, and Scotland, a firm that engages in only investment management is subject to an initial capital requirement of $€ 50,000$, which becomes $€ 125,000$ when the firm is permitted by clients to hold their assets. ${ }^{25}$ The processes for prior authorization differ within MiFID jurisdictions. In Ireland, for example, to receive authorization a prospective asset manager must have an in-person meeting with personnel of the Central Bank and then submit extensive information; the Bank must be satisfied, inter alia. as to the probity and competence of each of an applicant's directors and senior personnel. ${ }^{26}$ In Canada, registration and licensing is a provincial-level activity; in Ontario, individuals within the regulatory category of portfolio managers must have worked for at least a minimum period of time in the industry and must hold a designation as a CFA (Chartered Financial Analyst), unless the provincial regulator grants an individual exemption. $^{27}$

In striking contrast, registration as an investment adviser in the United States requires (unless the adviser is exempt) only compliance with disclosure requirements imposed by the Securities and Exchange Commission (SEC), both to prospective clients through a brochure covering eighteen items prescribed by the SEC and to the SEC through completion of a form. ${ }^{28}$ Although registration thus does not require that a prospective adviser satisfy initial capital

${ }^{25}$ See L. Van Setten \& T. Plews, 'England and Wales' para. 11.18 in Liability of Asset Managers. Asset managers in Scotland are subject to the same regulatory framework, including capital adequacy requirements. See D Cabrelli, 'Scotland' para 15.11.

${ }^{26}$ A. Bates \& B. Clarke, 'Ireland' para. 12.23-12.24, in Liability of Asset Managers.

${ }^{27}$ P. Hughes \& C. Jordan, 'Canada' paras. 14.50, 14.76-14.77, in Liability of Asset Managers.

${ }^{28}$ DeMott \& Laby, supra, paras. 13.29-13.30. 
requirements, belong to an investor compensation scheme,${ }^{29}$ or meet experience and credential requirements comparable to those in Ontario, registration is not without consequences. Most notably, registration subjects an adviser to examination by the SEC. ${ }^{30}$ Moreover, the registration form filed with the SEC - Form ADV—enters a publicly-accessible database. One indication of the potential significance of adviser registration forms is the recent media attention focused on directors of hedge funds, which became (unless exempt) subject to the requirement to register as advisers as a consequence of the Dodd-Frank legislation. ${ }^{31}$ Alert to this new source of data, the New York Times analyzed thousands of hedge-fund adviser filings and determined that many directors of funds organized in the Cayman Islands sit on the boards of twenty-four or more funds with different managers, while some directors hold more than one hundred directorships in Caymans-based funds. ${ }^{32}$ Some firms that supply directors also furnish legal services to funds, but industry sources cite a move toward greater independence and separation of services, all likely

${ }^{29}$ Clients of Bernard Madoff's Ponzi scheme were eligible for compensation from the Securities Investor Protection Corporation (SIPC) although SIPC does not encompass investment advisory accounts because as a registered broker-dealer Madoff's firm was a SIPC member, did not establish a separate business unit for the bogus advisory business, and used letterhead stationery to communicate with advisory clients that bore the SIPC member logo. See D. Henriquez, The Wizard of Lies: Bernie Madoff and the Death of Trust 222 (2011). SIPC insures customer accounts up to certain limits and provides mechanisms to liquidate failed broker-dealer firms.

${ }^{30}$ Id. para 13.33-13.37.

${ }^{31}$ Id. para 13.26 .

${ }^{32}$ A. Ahmed, 'In Caymans, It's Simple to Fill a Hedge Fund Board,' N.Y. Times, July 1, 2012. It is not unusual for directors of US-based mutual funds to sit on boards of multiple fund boards, but typically the funds are managed by the same adviser. 
heightened by the increased scrutiny of fund governance now enabled by adviser registration. ${ }^{33}$

\section{Industry-based self-regulation}

The extent and status of self-regulation through industry-based organizations differ markedly among jurisdictions. Likewise, external assessments of the potential strengths and pitfalls of self-regulation are far from unanimous. Supporters emphasize the superior information and responsiveness of industry-based regulation, while critics see mostly defensive and grudging efforts to hold government at bay. ${ }^{34}$ In Switzerland, as explained above, self-regulatory organizations (SROs) constitute a substantial component of the regulation of asset managers. At the opposite end of this spectrum, industry-based groups may represent the interests of their members but play no regulatory role. For example, the Luxembourg Bankers' Association (the ABBL) includes as members most banks, financial institutions, and financial professionals but the ABBL has no self-regulatory functions. ${ }^{35}$

One potential strength of industry-based regulation is its ability, if effective, to expand the reach of under-resourced and over-stretched public regulators. In the United States, the current question is whether SROs might serve as vehicles for enforcing regulatory rules, in particular by examining member firms to assess compliance, given the SEC's limited capacity to examine the population of 11,000 advisers registered with it. ${ }^{36}$ Investment advisers have not been

${ }^{33} \mathrm{Id}$.

${ }^{34}$ See R. Baldwin, Understanding Regulation 30, 39 (OUP 1999).

${ }^{35}$ I. Riassetto \& J.-F. Richard, 'Luxembourg' paras. 6.06, 6.60, in Liability of Asset Managers.

${ }^{36}$ DeMott \& Laby, supra para. 13.04. More than 15,000 advisers are registered with the states and not the SEC. Id. Under the Advisers Act, an adviser is prohibited from registering with 
subject by statute to an SRO, unlike broker-dealers; in response to a legislative mandate under Dodd-Frank, the SEC has recommended that Congress consider whether one or more SROs should examine advisers and whether the SRO for broker-dealers (the Financial Industry Regulatory Authority or FINRA) should examine advisers who are dually-registered as brokerdealers for compliance with the Advisers Act. ${ }^{37}$ Legislation currently pending in Congress would require an SRO for advisers, ${ }^{38}$ with FINRA assumed to be the lead candidate and disputes concerning projected costs. ${ }^{39}$ Much of this debate is overshadowed by Bernard Madoff's longrunning Ponzi scheme, which defrauded investors of billions of dollars and eluded detection for many years. ${ }^{40}$

\section{Conduct of business rules, in particular custody of client assets}

Jurisdictions in which investment managers are subject to specific regulation impose requirements applicable to the manager's conduct of its business. MiFID, for example, establishes a general obligation of acting honestly, fairly and professionally in accord with

the SEC if it is regulated by or required to be regulated by the state of its principal place of business, has less than $\$ 25$ million in assets under management, and does not advise a registered investment company (ie a mutual fund). Id para 13.22.

${ }^{37}$ Id. para 13.37 .

${ }^{38}$ See Investment Adviser Oversight Act of 2012, HR 2624.

${ }^{39}$ See M. Waddell, Bachus Reintroduces SRO Bill, Investment Advisor June 2012.

${ }^{40}$ DeMott \& Laby, supra, para 13.92. As it happens, Madoff was not required to register as an investment adviser until 2006 because his business relied on an exemption for registration available to broker-dealers that provided investment advice 'solely incidental' to broker-dealer activities under Advisers Act s 202(a)(11). Madoff registered once the SEC determined that any discretionary account must be treated as an advisory account. See id. at para 13.92. 
clients' best interests and in accord with a set of general principles. ${ }^{41}$ Many requirements operate more specifically, including tests requisite to fulfilling the 'know-your-customer' duties. ${ }^{42}$

Jurisdictions — including those subject to MiFID — differ significantly in their treatment of a manager's custody (or safeguarding) of clients' financial assets. Custody raises important issues because a manager's physical custody of, or control over, assets belonging to a client exposes the client to evident risks. The client may become subject to claims of the manager's own creditors; inadequate record-keeping may create confusion over asset ownership; the risk of conversion and other forms of misappropriation is evident; and managers' self-custody of client assets can facilitate fraudulent schemes that require fictitious statements of assets in clients' portfolios. To be sure, these risks can also arise when a third party holds clients' assets, and third-party custody may be more costly. Thus, perhaps it is unsurprising that jurisdictions diverge on the regulation of custody arrangements and, apart from formal regulation, in customary practices relevant to custody.

MiFID permits asset managers to hold financial instruments and funds that belong to clients, subject to a requirement that the manager make 'adequate arrangements' to safeguard assets were the manager to become insolvent and to prevent its use of clients' assets for its own account without clients' explicit consent. ${ }^{43}$ If the manager deposits client assets with a third

${ }^{41}$ MiFID art 19(1).

${ }^{42}$ An exception to the dominance of disclosure as a regulatory technique in the United States is the prohibition on performance-based fees in contracts between investment advisers and retail investors, applicable to SEC- and state-registered advisers. See Advisers Act s 205(a)(1), 15 USC s 80b-5(a)(1). For the rationales for this prohibition, see DeMott \& Laby, supra at para. 13.62 .

${ }^{43}$ Grundmann-van de Krol, supra, para 2.40. 
party, the manager has a duty to select the depository with due care, skill, and diligence.

Likewise, in the United States, an investment adviser may have custody of clients' financial assets, subject to a complicated SEC rule. ${ }^{44}$ In general, and subject to exceptions, an adviser with custody must agree that an independent public accountant may conduct a surprise examination. Recent events in the United States illustrate the risks associated with control over clients' assets, even that falling short of technical custody. The failed futures-trading firm MF Global Holding Ltd.- regulated not as an investment adviser but as a futures broker subject to the Commodities Futures Trading Commission (CFTC)—relied on an exemption from the categorical requirement that it segregate customer assets from its own that applied to customers with non-US accounts In the final desperate days before MF Global's bankruptcy filing, some $\$ 1.6$ billion of customer monies went missing, with $\$ 175$ million transferred to replenish an overdrawn bank account of MF Global itself. ${ }^{45}$ But customers with non-US accounts claim that 'they had no idea' just how vulnerable they were to the risks that the firm would use their assets to meet its own obligations and that they would be treated so differently from customers with no investments outside the United States. ${ }^{46}$ As a consequence, the entire futures industry came under a reputational black cloud. ${ }^{47}$

\footnotetext{
${ }^{44}$ Advisers Act r 206(4)-2, 17 CFR s 275.206(4)-2.
}

${ }^{45}$ See B. Protess \& A. Ahmed, 'MF Global's Shortfall No Surprise, Some Say', NY Times, March 28, 2012, at B1.

${ }^{46}$ A. Lucchetti, 'Customer Divide at MF Global', Wall St. J., May 7, 2012 at C2.

${ }^{47}$ In response, the exchange on which MF Global traded announced it would tighten its scrutiny of member firms. See J. Bunge, 'Exchange to Tighten Watch Over Client Funds,' Wall St J, April 5, 2102, at C3. 
In contrast, the regulation implementing MiFID in Italy contains no rules concerning managerial custody because custody of clients' assets falls within the regulatory powers of the Bank of Italy and is subject to its regulation. ${ }^{48}$ In Germany, only licensed banks may provide custodial services, ${ }^{49}$ and in Switzerland independent asset managers may not hold cash or securities accounts for customers. Separate from formal regulation, customary practice in a particular financial market may shape how custody is structured. In Poland, for example, firms that serve only as asset managers do not typically also serve as custodians of client's assets because the practice is that an a management client enters into a separate custody agreement with a bank or a full-service brokerage firm. ${ }^{50}$

Finally, managerial custody of clients' assets may combine high risks to the client with the prospect that regulation prohibiting the practice would foreclose conduct by a small number of managers that leads to liability. A categorical prohibition on such custody arrangements would foreclose the need for the kinds of complex regulation discussed above. Perhaps the overall costs of custody ultimately borne by clients would increase — perhaps — but it is important to remember that enforcement in the wake of a manager's abuse of custody is also costly. For example, to date the trustee pursing assets on behalf of victims of the Madoff Ponzi scheme has distributed \$ 1.1 billion (against $\$ 20$ billion in total losses on the trustee's determination) and is in a legal position to distribute billions more. ${ }^{51}$ But to accomplish this result, the trustee and his law firm

\footnotetext{
${ }^{48}$ M. Bet \& P. Guidici, 'Italy,' para 5.34, in Liability of Asset Managers.

${ }^{49}$ M. Casper \& C. Altgen, 'Germany' para 4.59, in Liability of Asset Managers.

${ }^{50}$ A.W. Kawecki, 'Poland' para 8.28, in Liability of Asset Managers.
}

51 This is because the trustee's determination of total losses has been dispositively upheld 
have charged more than $\$ 270$ million in fees. ${ }^{52}$

\section{CONCLUSION}

As this brief Comment illustrates, many issues concerning the regulation of asset

managers are challenging at many levels. Additionally, many are highly topical. The variety of regulatory techniques sketched in the Comment may imply that asset management raises issues distinct to particular jurisdictions, to which the jurisdiction responds through a distinctive set of regulatory choices.

by the courts, and the Supreme Court of the United States did not intervene. See P. Lattman, Supreme Court Declines to Hear Madoff Dispute, NY Times, June 25, 2012, referring to In re Bernard L. Madoff Inv. Securities LLC, 654 F3d 229(2d Cir 2011), certiori denied, 2012 WL 396489 (US June 25, 2012). The trustee calculated total recoverable losses based on the difference between amounts invested with Madoff and cash withdrawn by investors, which limited total recoverable claims to those of 'net losers' who withdrew less cash from their Madoff accounts than they had invested. 'Net winners,' who unsuccessfully challenged this basis for calculation, would have based total losses on the amounts shown on the account statements they received from Madoff, which would have resulted in total losses of $\$ 60$ billion and fewer of the recovered monies going to the 'net losers.'

\footnotetext{
${ }^{52}$ Lattman, supra.
} 